\title{
Preliminary Reflexion on Basic Principle of Infrastructure Asset Management
}

\author{
Pemikiran Awal tentang Prinsip Dasar Manajemen Aset Infrastruktur
}

\author{
Hitapriya Suprayitno ${ }^{1, a)}$ \& Ria Asih Aryani Soemitro ${ }^{1, b)}$ \\ ${ }^{1)}$ Civil Engineering Department, Institut Teknologi Sepuluh Nopember (ITS), Surabaya, Indonesia. \\ Correspondant : a) suprayitno.hita@gmail.com \& ${ }^{\text {b) }}$ soemitroraa@gmail.com
}

\begin{abstract}
Infrastructure is vital for regions life, mean while the infrastructure is always onerous and complex. The region must be able to manage its infrastructure well. Therefore the Basic Principle of Infrastructure Asset Management need to be well defined. This paper presents the result of an attempt to define the Basic Principle Infrastructure Asset Management. The Infrastructure Asset Management is defined as the science, the knowledge and the program to manage the infrastructure life in order to be able to well function in sustainable way, efficient and effective. The Infrastructure Asset Management knowledge consists of 7 basic knowledges, i.e on infrastructure, infrastructure function, infrastructure physical structure infrastructure externalities, infrastructure life cycle, infrastructure economy, and infrastructure managing organization. To master the Infrastructure Asset Management analyse tools must be added such as: statistics, decision making, risk management, quality management, strategic management, etc.
\end{abstract}

Keyword : infrastructure asset management, basic principle.

\section{INTRODUCTION}

Infrastructure is vital for region's life: economic, social and administrative life. Infrastructure procurement needs a lot of fund and technically, infrastructure is not a simple object. However, funding is always limited. Infrastructures are deliberately built to fulfill a certain function absolutely needed. Therefore, the infrastructure must be well managed in order that the infrastructure can be always functional, economic, effective, efficient and sustainable.

Basic Principle of Infrastructure Asset Management can be found in several articles (Arifiani 2017, ISO 55000, Suprayitno \& Soemitro 2016). But a complete and concise explanation about Infrastructure Asset Management still can not be found. For well understanding of Infrastructure Asset Management concept, to be able to well manage the infrastructure, the Basic Principle of Infrastructure Asset Management need to be developed and written.

In this journal three articles on Infrastructure Asset Management have been published. Those three discuss about: optimization method for a certain vehicle routing problem - related to operation management, simulation method for calculating facilities needed for ticketing service - related to infrastructure planning and reclaimed asphalt material characteristics related to the infrastructure's structure efficiency (Suprayitno \& Soemitro 2017, Susanti, Soemitro \& Suprayitno 2017, Widayanti et al 2017). Basic Principle of Infrastructure Asset Management needs to be written in this journal. This paper will serve as the base for other following papers. 
For this first attempt the Basic Principle is constructed for the infrastructures under the responsibility of the Ministry of Public Works and Public Housing. Regarding the Public Works and Public Housing Infrastructure, the infrastructure are classified into 4 infrastructure sectors: Water Resources Infrastructures, Road and Bridge Infrastructures, Sanitation Infrastructures, and Public Housing Infrastructures (Suprayitno \& Soemitro 2016).

Those the Basic Principle of Infractructure Asset Management needs to be defined and developed. This paper present the first attempt to defined the Basic Principle of Infrastructure Asset Management.

\section{RESEARCH METHOD}

As the research objective is to define the Basic Principles of Infrastructure Asset Management, the research was conducted by developing the Infrastructure Asset Management Concept. The concept development itself was started by understanding the infrastructure, infrastructure function, infrastructure physical structure, infrastructure life cycle, infrastructure externalities, infrastructure economic, infrastructure managing organisation and finished by developing the Basic Principle of Infrastructure Asset Management.

\section{LITERATURE REVIEW}

\section{Infrastructure}

Infrastructure can be defined as a man made structure needed for a region's public life, an entreprises life or also a household life. Examples of infrastructure are: road, bridges, railways, dam, electrical grid, etc. (Wikipedia, 2017a).

\section{Asset}

Asset can be defined as something valueable. Asset can be clasified into tangible asset and intangible asset. Tangible assets are physical assets, such as dam, solid waste incineration, port, prison, railway, electrical generator, etc. While examples of intangible assets are money, intelectual product, organization, etc. (Wikipedia, 2017b).

\section{Management}

Management is knowledges, sciences or program to manage an organization. The organization can be an entreprise, a non-profit organization or a government body. Basically, it can be said that the management consists of four basic steps: planning, organizing, actuating and controlling (Wikipedia 2017c).

Later on, the word management is also used to denote traffic management, irrigation management, hospital management, pavement management, etc. Traffic Management deals with implementing traffic engineering technique for traffic fluidity and safety. Irrigation management is a systematic approach to plan, to construct, to operate and to maintain an irrigation system, aims at increasing and maintaining irrigated agriculture productivity. Hospital management deals with the hospital operation in order to produce health care services efficiently. Pavement management is a systematic approach to providing, evaluating asset, it is requiring decision making at strategic network and project levels (FAO 2010; Grant et al 2002; Hopp \& Lovejoy 2013; Khan 2006; Trafikverket 2010; Uhlmeyer, Luhr \& Rydholm 2016).

\section{DEVELOPMENT OF BASIC PRINCIPLE}

The Basic Principles of Infrastructure Asset Management is developed based on the Asset Management definition and several basic knowledges. The related basic knowledges are as follows: Infrastructure, Infrastructure Function, Infrastructure Physical Structure, 
Infrastructure and Externalities, Infrastructure Life Cycle, Infrastructure Economics, Infrastructure Management, Infrastructure Managing Organisation, Infrastructure Asset Management and Tools for Analysis.

\section{Preliminary Definition}

Infrastructure Asset Management can be imagined as tasks that the infrastructure manager should do in order to maintain the Infrastructure Function, and it deals with the infrastructure present condition. We can imagine that the manager, in his control room, watchs the data in the computer and is helped by several staffs, decide the task to be executed. The data, the manager watch, must be the data on the infrastructure existing condition and regional data for which the infrastructure serve.

It can be imagined that the main tasks the infrastructure manager has to deal with, on his daily work, among others are:

- Are the infrastructures function well?

- Is the infrastructure operation well enough?

- What kind of infrastructure operation improvement need to be installed?

- Are the infrastructure well maintained?

- What maintenance program must be planned?

- Are the infrastructures need to be developed?

- Are the infrastructures need to be disposed?

- Do we need new infrastructures?

- How much fund needed to manage the infrastructures?

- How much fund is available?

\section{Infrastructure}

Infrastructure is any kind of man made structure needed for public life, and private life such as: dam, road, bridge, drainage, irrigation, waste water treatment installation, railway, port, airport, etc. Infrastructure is built, because the infrastructure is needed to perform a certain function for the shake of the population in a certain region.

Example of four types of Public Works and Public Housing infrastructure are dam, road, solid waste yard, low cost rental apartment. The example of those infrastructure are presented in Figure 1 below.

Instead of the infrastructure type, within each infrastructure type, infrastructure is normally classified into one or more classification. Road for example are classified into functional classification, status classification and road class classification.

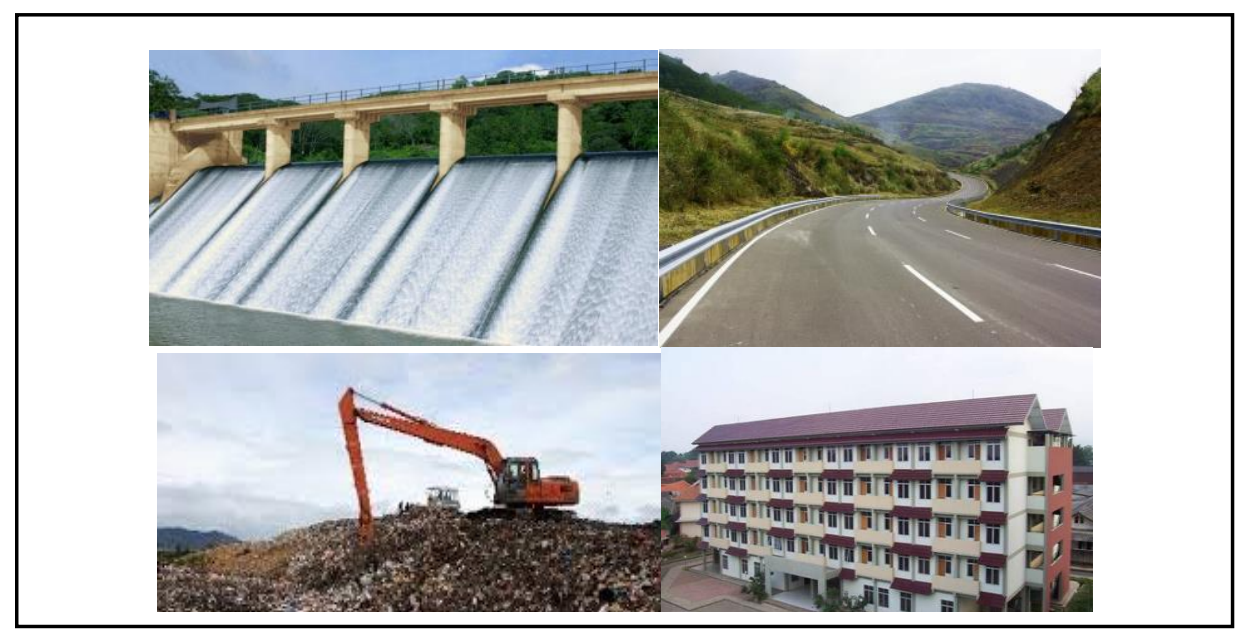

Figure 1. Example of Public Works Land Public Housing Infrastructure 


\section{Infrastructure Function}

Infrastructure is built to execute certain particular function. Each infrastructure has its own particular function. Therefore, the infrastructure function is very important to be well understood and well defined. An infrastructure may has the main function and the other secondary fuctions. Examples of Infrastructure function is presented in Table 1 below.

Table 1. Example of Infrastructure Function

\begin{tabular}{lll}
\hline Infrastructure & Main Function & Secondary Functions \\
\hline Dam & $\begin{array}{l}\text { to retain water to be distributed for irrigation } \\
\text { and other purposes }\end{array}$ & fishery, tourism \\
\hline Road & to flow traffic & for advertising \\
\hline $\begin{array}{l}\text { Waste } \\
\text { Incinerator }\end{array}$ & to burn solid waste & for professional training \\
\hline $\begin{array}{l}\text { Low Cost } \\
\text { Apartment }\end{array}$ & to facilitate housing for the poor people & $\begin{array}{l}\text { facilities for small scale } \\
\text { commerce }\end{array}$ \\
\hline
\end{tabular}

\section{Infrastructure Physical Structure}

Each infrastructure has its own special physical structure. The physical structure can be quite diferrent one to others. It is also very important to denote the infrastructure physical structure. Example of physical structure is presented in Table 2 below.

Table 2. Infrastructure Component

\begin{tabular}{ll}
\hline Infrastructure & Component \\
\hline Dam & dam, spill way, irrigation intake, etc \\
\hline Road & pavement, side walk, road mark, road sign, drainage etc \\
\hline Solid Waste Incinerator & main building, incinerating room, truck route, office, etc \\
\hline Low Cost Apartment & apartment building, sanitation infrastructure, etc \\
\hline
\end{tabular}

\section{Infrastructure Life Cycle}

Related to Infrastructure Asset Management, the infrastructure life cycle must be well understood. The infrastructure life cycle should be determined into the following 8 steps.

- Infrastructure Policy Infrastructure Policy is about defining the policy direction of infrastructure development.

- Infrastructure Idea Infrastructure idea is about to develop preliminary idea of infrastructure solve the existing problem.

- Infrastructure Planning Infrastructure planning englobe the work of infrastructure to master plan development, infrastructure feasibility study, infrastructure programming, infrastructure financing study.

- Infrastructure Design Infrastructure Design is about to develop the infrastructure Detail Engineering Design, Contruction Cost, Contract Document.

- Infrastructure Construction Infrastructure Construction is about the whole process of infrastructure construction, started from contruction tender up to professional hand-over. 
- Infrastructure Certification, Information System

Infrastructure Certification, Information System are about to do functional certification, to develop the appraisal for the data base, to develop or to update the information system.

- Infratructure Utilisation

Infrastructure Utilisation englobe the Infrastructure Operation and Infrastructure Maintenance.

- Infrastructure Disposal

Infrastructure Disposal is about the whole process to dispose an infrastructure.

- Infrastructure Evaluation

Infrastructure evaluation is about evaluating the infrastructure related to the operation, maintenance, the function performance, the evaluation result is needed to formulate the next infrastructure program on development, operation and maintenance.

The infrastructure life cycle as presented above, can be presented as a flowchart diagram in Figure 3 below.

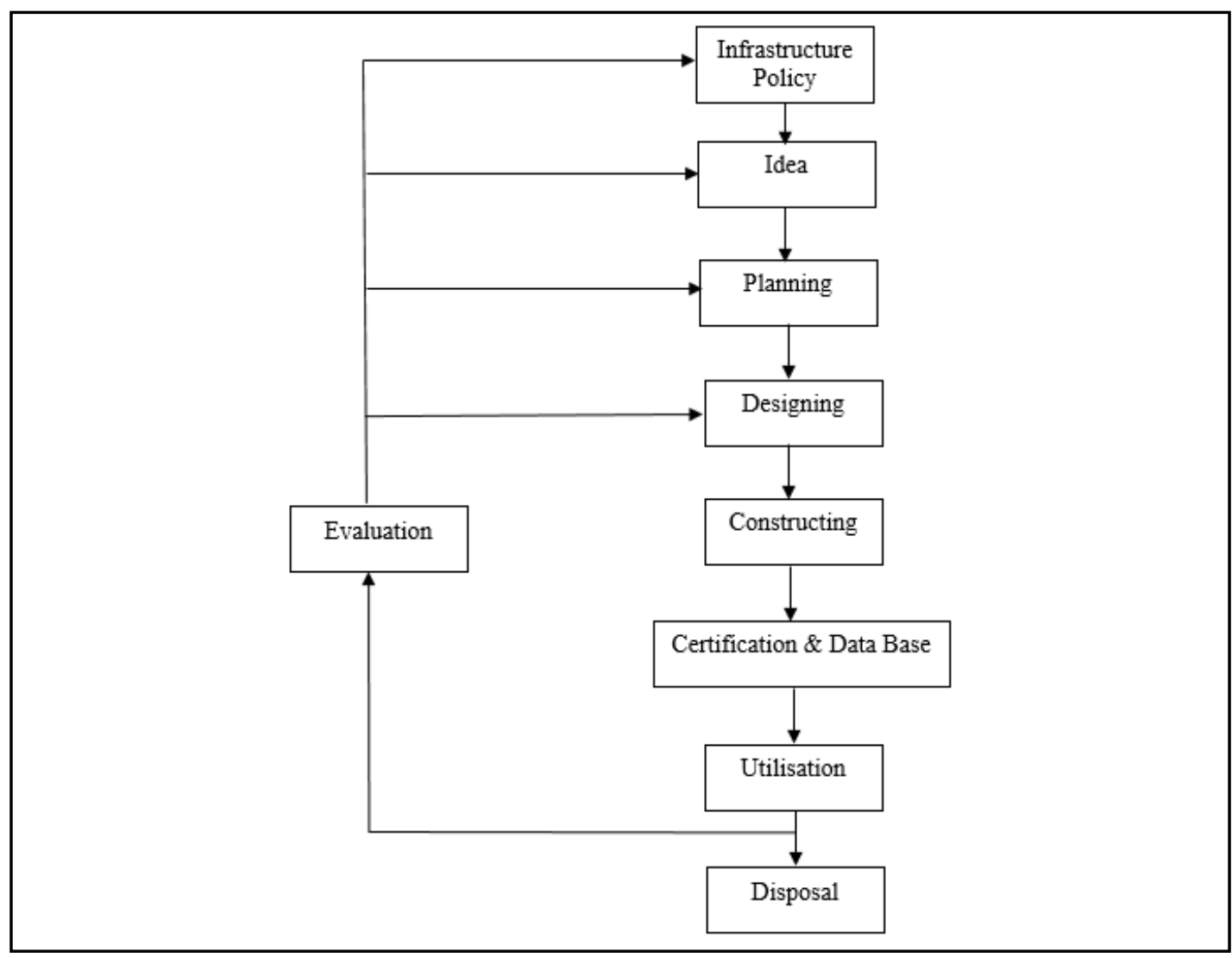

Figure 2. Infrastructure Life Cycle

\section{Infrastructure Economics}

Regarding the Infrastructure Economic cannot be separated from the Principal of Regional Economics.

The infrastructure economic knowledge must be classified into basic infrastructure economic characteristics, micro-economic analysis, meso-economic analysis and macroeconomic analysis. Each infrastructure has its own basic economic characteristics: either free use or payed use infrastructure, either symbolique or economic infrastructure, cost 
characteristics, financial/economic benefit characteristics. Microeconomic analysis deals with the economic/financial feasibility, maintenance cost optimization, etc. Meso-economic analysis deals with the economic of infrastructure managing organization. Macro-economic analysis deals with relation between the infrastructure and regional economy.

Life cycle cost is a well known term, this is about the infrastructure cost for each life cycle step. Each step cost are related each other. In-efficient infrastructure design can produce in-efficient operation and maintenance. Therefore, understanding and managing life cycle cost is very important.

\section{Infrastructure and Externalities}

The infrastructure have an interaction with the region's population, the region's geographical condition, the region's environment condition, the region's land use and the infrastructure management institution. The infrastructure must be in accordance to the related codes. It if can be said thet infrastructure have externalities.

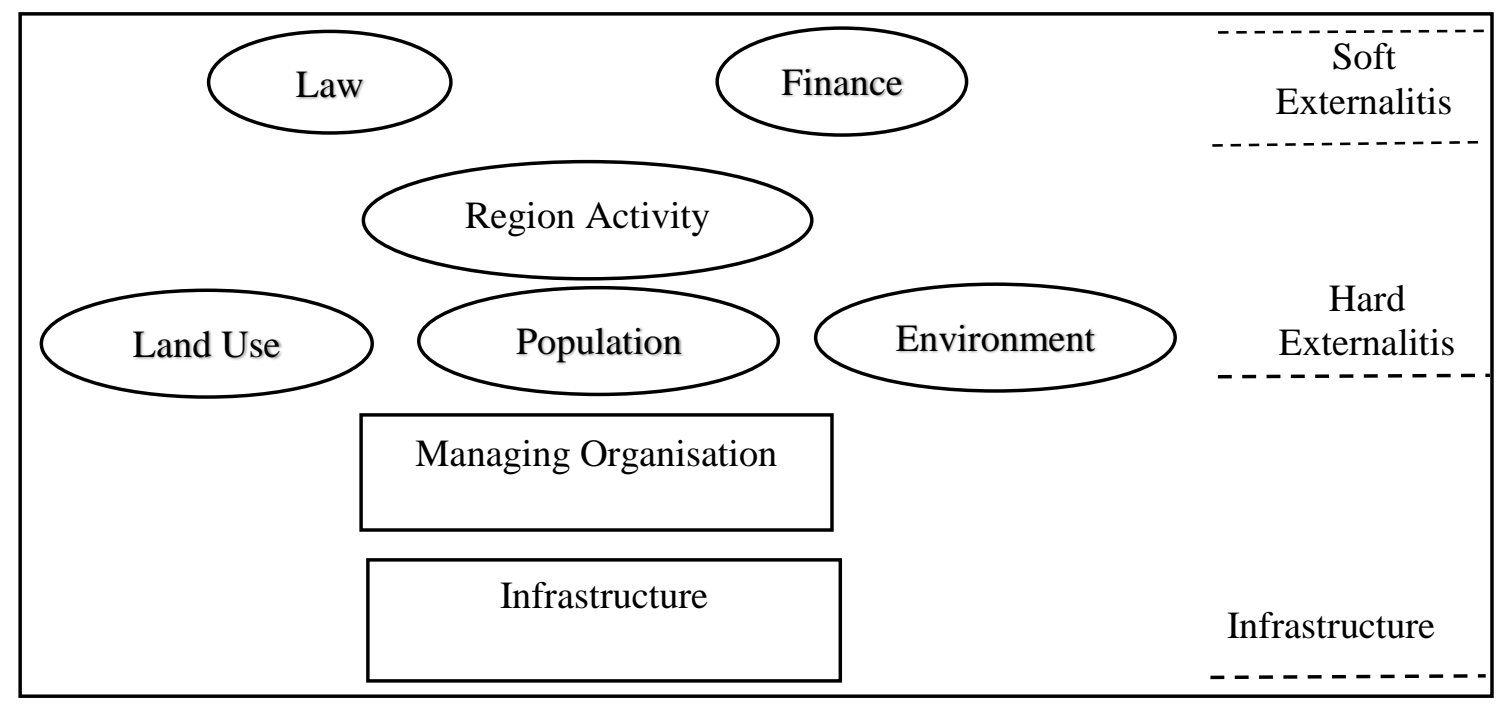

Figure 3. Infrastructure and Externalities

\section{Infrastructure Managing Organisation}

Infrastructures are always managed by an infrastructure managing organization. Related to the Managing Organisation there is Organisation Management knowledge.

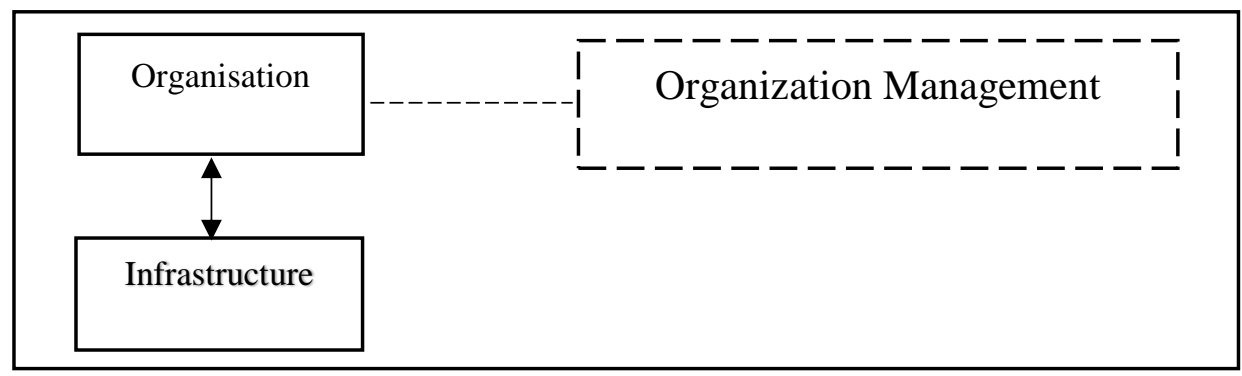

Figure 4. Infrastructure and Organisation

\section{Infrastructure Management}

By Basic Principle, Insfrastructure Asset Management is a task, knowledge and science to manage the infrastructure, through the whole of its life cycle, in order that the infrastructure be able to sustainably function effectively, efficiently and in accordance with sustainable principle. (economic, social, \& environmental). 


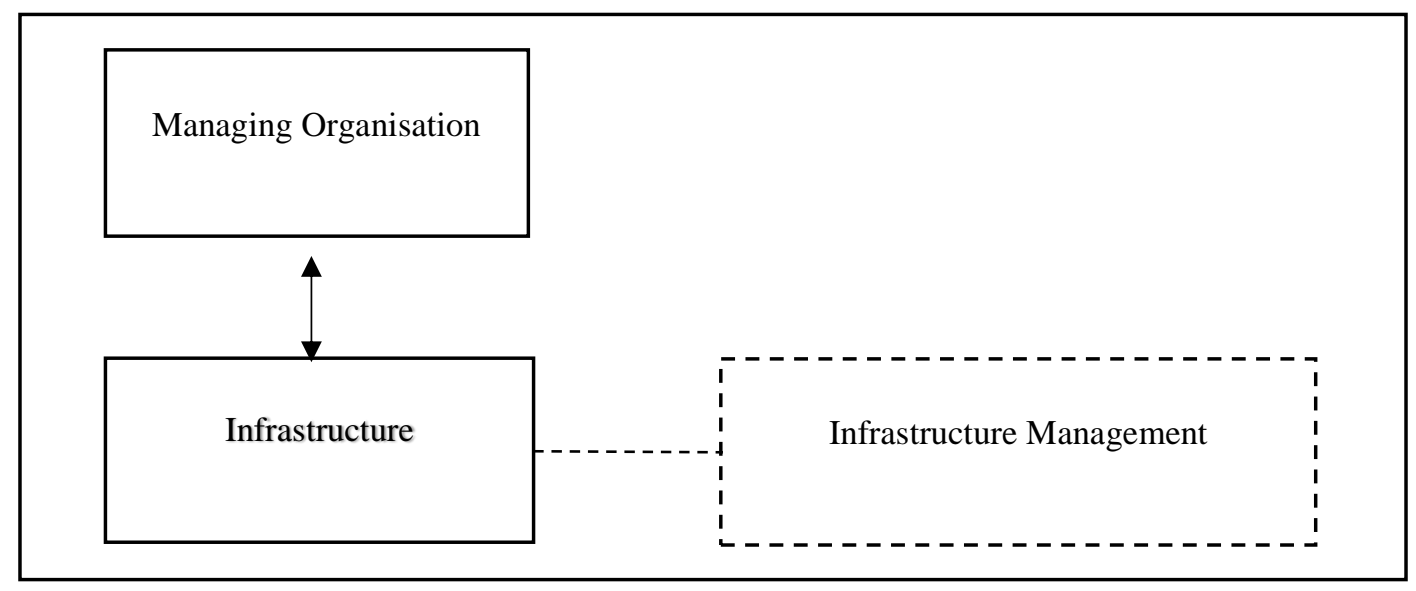

Figure 5. Infrastructure Asset Management

Those the Infrastructure Management deal with the strategical aspect of each life cycle step. Problem concerning each step can be mentioned as follow:

- Infrastructure Policy : formulating and/or assessing infrastructure policy

- Infrastructure Idea : creating the infrastructure basic idea

- Infrastructure Planning : planning guide line and strategy

- Infrastructure Design : design guide line, strategy, developing a master plan

- Infrastructure Construction : construction programming, contract system

- Infrastructure Certification : appraisal, information system, certification

- Infrastructure Utilisation : operation and maintenance management

- Infrastructure Evaluation : evaluation method and guidline

- Infrastructure Disposal : disposal decision making and guide line

\section{Tools for Analysis}

The Infrastructure Asset Management analysis and programming need certain Tools for Analyse such as :

- Operation Research

- Statistics

- Decision Making

- Risk Management

- Quality Management

- Strategic Management

\section{Infrastructure Asset Management}

Infrastructure Asset Management can be regarded as consists of the infrastructure management and also the organization management. But the main knowledge is still concering the Infrastructure Asset Management. This is not a simple and easy knowledge and science.

\section{CONCLUSIONS}

Reflexion objective has been attained, the Infrastructure Asset Management has been defined based on the following principles :

- Infrastructure Asset Management is knowledge, science or program to manage the infrastructure in order to be able to execute its function sustaibably, effectively, efficiently and always conform to the suistanability principle. 
- The IAM knowledge basically should unsits is basic knowledge on

- Organisation Management

- Infrastructure : type, class

- Infrastructure Function : main function and secondary function

- Infrastructure Structure : main parts and supporting parts

- Infrastructure Life Cycle : 8 steps of life cycle Infrastructure and Externalities.

- Infrastructure Economic : economic type, benefit characteristics, life cycle cost.

- Infrastructure Externalities

- Infrastructure Codes and Regulations

This Basic Principle must be developed further by developing explanation of Infrastructure Asset Management Works for each step of infrastructure life cycle.

Acknowledgement. This paper is the first step torward developing Infrastructure Asset Management Knowledge and Science.

\section{REFERENCES}

Arifiani, N., Suprayitno, H. \& Indryani, R. (2017). "Development of Office Building Asset Management, Standard for Public Work Highway in Jember District". IPTEK Journal of Proceeding Series, Issue 2, pp : 55 - 59. 2017. Institut Teknologi Sepuluh Nopember (ITS). Surabaya.

FAO (2010). Irigation Management. FAO - Land and Water Division. Rome.

Grant, M. et al (2002). "Water Management and Waste Water Treatment at The University of British Columbia : A Study for Suistainable Alternatives". Thesis. University of British Columbia. Vancouver.

Hopp, W.J. \& Lovejoy, W.S. (2013). Hospital Operations : Principles of High Efficiency Health Care. FT Press. New Jersey.

ISO 55000. Asset Management.

Khan, Jawed Ali (2006). Hospital Waste Management Issues and Steps Taken by The Government of Pakistan. Ministry of Environment. Islamabad.

Suprayitno, Hitapriya (2014). ”Metoda Analisis Kualitas Jaringan Jalan”. Disertasi. Jurusan Teknik Sipil. Institut Teknologi Sepuluh Nopember (ITS). Surabaya.

Suprayitno, H. \& Soemitro, R.A.A. (2016). "Basic Notion of Infrastructure Asset Management, what UNIID should do?”. IPTEK Proceeding, Series, Issues, 2017. Institut Teknologi Sepuluh Nopember (ITS). Surabaya.

Suprayitno, H. \& Soemitro, R.A.A. (2017). "Upaya Awal Optimasi Jumlah Kendaraan Angkut pada Kasus Umum Pengangkutan Obyek dari n Titik Asal ke 1 Titik Pengumpulan". Jurnal Manajemen Aset Infrastruktur \& Fasilitas, Vol.1, No.1, Desember 2017. Institut Teknologi Sepuluh Nopember (ITS). Surabaya.

Susanti, A., Soemitro, R.A.A, \& Suprayitno, Hitapriya (2017). "Metoda Simulasi Bagi Perhitungan Kebutuhan Jumlah Tempat Duduk Pada Fasilitas Reservasi Tiket". Jurnal Manajemen Aset Infrastruktur \& Fasilitas, Vol.1, No.1, Desember 2017. Institut Teknologi Sepuluh Nopember (ITS). Surabaya.

Trafikverket (2010). Road Traffic Management - For efficient, safe and environmentally sound journey sand transport. Swedish Transport Administration. Borlänge.

Uhlmeyer J., Luhr D., \& Rydholm, (2016). Pavement Asset Management. Washington State Department of Transportation. Olympia..

Widayanti, A., Soemitro, R.A.A, Ekaputri, J. \& Suprayitno, Hitapriya (2017). "Karakteristik Material Pembentuk Reclaimed Asphalt dari Jalan Nasional di Provinsi Jawa Timur". 
(e)ISSN 2615-1847 (p)ISSN 2615-1839

Jurnal Manajemen Aset Infrastruktur \& Fasilitas - Vol. 2, No. 1, Maret 2018

Jurnal Manajemen Aset Infrastruktur \& Fasilitas, Vol.1, No.1, Desember 2017. Institut Teknologi Sepuluh Nopember (ITS). Surabaya.

Wikipedia (2017a).’Infrastructure". Wikipedia, downloaded 5 December 2017.

Wikipedia (2017b)."Asset". Wikipedia, downloaded 5 December 2017.

Wikipedia (2017c).”Management”. Wikipedia, downloaded 5 December 2017. 
(e)ISSN 2615-1847 (p)ISSN 2615-1839

Jurnal Manajemen Aset Infrastruktur \& Fasilitas - Vol. 2, No. 1, Maret 2018 